Article

\title{
The Role of the 'Cities for Change' in Protecting the Rights of Irregular Migrants in Spain
}

\author{
Belén Fernández-Suárez * and Keina Espiñeira \\ Department of Sociology and Communication Sciences, University of A Coruña, 15071 A Coruña, Spain; \\ E-Mails: belen.fernandez.suarez@udc.es (B.F-S.), keina.espineira@udc.es (K.E.) \\ * Corresponding author
}

Submitted: 31 October 2020 | Accepted: 14 December 2020 | Published: 27 April 2021

\begin{abstract}
Have the new municipalist pro-migrant policies succeeded in protecting the rights of irregular migrants? Cities in Spain have powers to design and implement services and programs aimed the reception and integration of immigrants. Cities can also include those who are in vulnerable conditions, guaranteeing them access to healthcare, minimum income coverage or labour training, regardless of the immigration status. However, old municipal politics have been characterised by pragmatism, being mainly focused on regular immigrants. Besides, there has been a restrictive and punitive turn in immigration policy directly connected to the economic recession and austerity as of 2008. To explore what possibilities do cities have to expand and protect the rights of irregular immigrants, we analyse in this contribution the cases of Madrid and Barcelona for the years 2015-2019 when progressive municipalists fronts ruled the cities. Based on the textual analysis of policy documents and in-depth interviews with political parties, street-level bureaucrats and activists, we first examine the competencies that municipalities have in migration matters and mainstream approaches in Spain. Then we discuss the action of the new municipalism, focusing the analysis on four political measures that have been rebel and innovative in protecting irregular immigrants, namely, the proactive census, the prevention of irregularity, access to healthcare and changes in police protocols. These real experiences allow us to argue that cities can achieve changes in the way state control is enforced. However, the analysis also shows tensions between the political will and institutional constraints.
\end{abstract}

\section{Keywords}

Barcelona; cities; citizenship; immigration; institutional change; integration; Madrid; municipalism; Spain; welfare

\section{Issue}

This article is part of the issue "Migration-Led Institutional Change in Urban Development and Planning" edited by Robert Barbarino (TU Dortmund University, Germany), Charlotte Räuchle (Free University Berlin, Germany) and Wolfgang Scholz (TU Dortmund University, Germany).

(C) 2021 by the authors; licensee Cogitatio (Lisbon, Portugal). This article is licensed under a Creative Commons Attribution 4.0 International License (CC BY).

\section{Introduction}

Over the course of the last two decades, liberal states have undergone a shifting from promoting policies that expand social and civil rights to restricting access. This "restrictive turn" (de Hass, Natter, \& Vezzoli, 2018) came later to Spain than to other European states. It is particularly during the economic recession as of 2008 that austerity policies and the lack of political will started to undermine state integration policies. Until then, Spain was characterised by a more open approach towards immigration, explained by the segmentation of the labour market with high levels of informality and the limited character of welfare that is supported by familialism-being this a feature of welfare-states in southern Europe. This is characterised by late development, low social spending and a mixed level of protection where the family plays a relevant role in the provision (Arango, 2013; Peixoto et al., 2012).

After the crisis of 2008, the state launched a series of measures making access to welfare limited for immigrants. The introduction of new criteria for 
civic integration in the Aliens Law (Spanish Government, 2009), making residence and work permits conditional to it, marks the beginning of this restrictive turn. At that time, the Socialist Party (PSOE) ruled the state level. When in 2011, the government changed to the People's Party (PP) - a more liberal conservative tendency, it approved a series of legislative initiatives that made much more difficult to lead an ordinary life for irregular immigrants. The exclusion from healthcare coverage by Law 16/2012 was particularly controversial (Spanish Government, 2012b).

The adoption of austerity policies as a way out of the crisis and the reduction of social investment in the budgets of the administrations increased social inequalities and poverty (see Bruquetas-Callejo \& MorenoFuentes, 2015; Pedreño, Moraes, \& Gadea, 2015; Treviño \& González-Ferrer, 2016). Under these circumstances, the role of cities managing the integration of immigrants was severely affected (López-Sala, 2013), especially for those at risk of social marginalisation and exclusion due to precarious legal statuses. Brandariz-García and Fernández-Bessa (2017) show how social cuts and the consequent restrictions in access to welfare have had a significant impact on increasing immigration control in the cities. The extension of identification, detention and deportation practices also involved what has been conceptualized as a "punitive turn" (Bosworth, Franko, \& Pickering, 2017) that affected to the criminalisation immigrants (Moffette, 2020).

In the midst of this context of incipient hostility, referring to a condition of fear and uncertainty that increasingly penetrates different aspects in the daily life of immigrants (Berg \& Fiddian-Qasmiyeh, 2018), the May 2015 local elections marked a change. It leaded to the emergence of a new municipalism characterised by the promotion of a participatory approach to co-produce urban policies (Blanco, Gomà, \& Subirats, 2018; Subirats, 2018). Following the cycle of social mobilisation known as ' $15 \mathrm{M}$ ' the impact was not minor, large and medium cities such as Barcelona, Madrid, Valencia, Cadiz, Zaragoza and A Coruña (among others), became governed by new municipalist candidacies that manifestly questioned austerity and neoliberal policies. The constitution of the so-called 'cities for change' stands on the grounds of policies that promote inclusiveness and social equity (Blanco et al., 2018). As Russell (2019) argues, rather than essentialising cities as inherently progressive, the municipal became framed as a "strategic front" for developing a transformative politics of scale. The novelty was the recognition of the cities' leading role in making more inclusive societies and it was, at this point, where immigration politics acquired particular relevance. The rationale for the migrant struggles was the recognition that irregular migrants are de facto residents of the cities they inhabit (Bauder, 2014; Bauder \& Gonzalez, 2018). This was made possible by the previous work of urban social movements drawing up alliances between activists and migrants against precariousness and police perse- cution (see Casas-Cortes, 2019; Fernández-Bessa, 2019). These alliances have been expanded through national and international connections, such as the Spanish network Refuge Cities, the European Solidarity Cities and the global municipalist movement Fearless Cities. Barcelona, in particular, was highly proactive in its relations with other sanctuary cities (see Bauder \& Gonzalez, 2018; Christoph \& Kron, 2019; Garcés-Mascareñas \& Gebhardt, 2020; García-Agustín \& Jørgensen, 2019).

Following this line of reasoning, in this contribution we wonder whether local pro-migrant policies have managed to expand the rights of irregular immigrants, and to what extent it is possible to improve their lives at the local level when the state is restrictive and punitive. We analyse the cases of Madrid and Barcelona in the years 2015-2019, when they become governed by municipalist fronts. We examine how these cities have enacted rebel and innovative policies to ensure access to social services, and to protect and avoid criminalisation of irregular immigrants. 'Irregular immigration' refers here to foreigners who do not meet the regular administrative procedures for stay or residence, as established by the Aliens Law (Spanish Government, 2009). This situation is caused in most cases not by irregular entry, rather than by the permanence after expiring entry visas. In this vein, irregularity occurs largely because the legal mechanisms to obtain residence or work permits are scarce and difficult (see Düvell, 2011).

The structure of the analysis is as follows. After this introduction, we describe the qualitative methodology in data collection. Then, we examine the decentralisation of powers in immigration policies and the main instruments that have characterised municipal old politics in Spain. Following, we delve into the examination of four innovative set of policies, namely: 1) proactive policies facilitating registration in municipal censuses, 2) measures to avoid administrative irregularity, 3) actions aimed at ensuring universal healthcare, and 4) changes in police protocols. These are illustrative cases of how cities can counterbalance the way state control is enforced. Then, to further understand the action and powers of municipalities in implementing progressive immigration policies, we analyse the contradictions between the political will and the institutional constraints of actual management. We examine the dilemmas faced by the new municipalism and what the limitations are. Finally, in the conclusion section we highlight some of the research findings.

\section{Methodology}

This research has been carried out based on a qualitative methodology that combines textual analysis and semi-structured interviews. We conducted 12 qualitative interviews based on two time series, before (2010-2011) and after the municipal elections (2015-2019). Coupled with the previous study of municipal immigration policies in the cities under analysis (Madrid and Barcelona), 
this enables us to contrast the information gathered in 2010-2011 with the specific information obtained in 2019. During the 2015-2019 legislature, we interviewed six key informants involved in the new municipal governments ruled by Madrid Now (Ahora Madrid) and Barcelona in Common (Barcelona en Comú) citizen platforms. The interviewed profiles were policymakers, street-level bureaucrats, and political advisers. In order to contrast changes in the approach to reception and integration services, we included in the analysis other six qualitative interviews conducted with the same profile of stakeholders, when these cities were not yet governed by municipalist fronts, specifically in the years 2010 and 2011.The interviews were audio-recorded and transcribed for analysis using Atlas.ti software. Broad thematic coding categories were prepared based on the theoretical framework and research questions of the overall research project, and these were expanded and refined into specific codes through the data collection process based on the emerging trends. Data was coded separately by two researchers, and discrepancies were resolved through consensus. In the writing of this article, we re-examined data codes related to new political proposals, namely, conflicts between social movements and institutions, measures aimed to avoid administrative irregularity, criminalisation, and measures facilitating access to rights and social welfare.

Concerning the textual analysis, we examined existing legal and policy documents (Barcelona City Council, 2005, 2019), and more concretely plans (Barcelona City Council, 2018a; Madrid City Council, 2017a), regulations and working documents (Barcelona City Council, 2015, 2016, 2017, 2018b; Madrid City Council, 2016, 2017b, 2018). These documents were provided by the interviewees and also were found through the search carried out on institutional websites. We also examined the programs for the 2015 elections of the citizen platforms Madrid Now and Barcelona in Common, as well as major newspapers published on those dates to observe the press coverage given to the policy measures discussed here (EI País, El Mundo, ABC and, in the case of Barcelona, also La Vanguardia and El Periódico de Cataluña).

Based on previous empirical analyses (Fauser, 2008; Fernández-Suárez, 2018; Morales, Anduiza, Rodríguez, \& San Martín, 2008; Morén-Alegret, 2001) we found that Madrid and Barcelona could be relevant cases for examination due to several reasons. First, due to their demographic size and composition. These are the most populated cities in the country, with 3,2 and 1,6 million respectively, and those that attract the largest number of the foreign population. One of the important differences in the nature of local reception and integration policies derives from the composition and weight of the migratory flows. The weight of the foreign population registered in Barcelona stands at $18 \%$ and Madrid is $13 \%$ over the total population (National Statistics Institute, 2018). Both cities absorb $10 \%$ of the population, but their level of potential attraction is greater for foreign residents of which $15 \%$ choose to live here. The second element for the choice of these cities was the institutional tradition and experience that both have had in the attention to immigrant populations. Finally, the third element of interest was the value that immigration politics acquired under the new municipalism legislature (2015-2019). Madrid and Barcelona developed a high number of programs and responsibilities in this area and, as we will see, this is due to the radical nature in their conception of politics and doing politics. We find here novel elements of migration urban design policies that can be shared with other cities, as illustrates the network of international connections like Fearless Cities, promoted by Barcelona's Council in 2017 (see Russell, 2019). But before going through these innovative rebel aspects in immigration politics (Section 4), we examine now the decentralisation of competencies and the mainstream approach that cities have had in Spain.

\section{Immigration Old Politics at Municipal Level}

City councils are central institutions in managing the accommodation of immigrants in Spain. The state has exclusive jurisdiction in immigration matters, however, in the areas of reception and integration, regional governments and municipalities have been primarily responsible in the policy design and implementation. This decentralisation of powers took place in the 1990s, after the approval of the first Aliens Law (Spanish Government, 1985).

Municipalities have two main competencies since then: the incorporation of foreigners into the census and the provision of social services and social inclusion. Municipal censuses are the key instrument to do so. These are administrative records where local residents have the right to be registered. In most cases, migration status is not checked. However, registration does not imply the recognition of residence or work permits, so far these are state's exclusive responsibility. Despite this, the municipal census functionality is significant. It gives access to fundamental rights such as health and education under the criteria of being member of the community and, importantly, by ensuring that the registration does not imply police persecution (Gonzalez-Enriquez, 2009).

Concerning the areas under municipal responsibility we find housing, healthcare services, security, cultural and educational promotion, economic promotion through labour training and programs for children, youth, gender equality and seniors. Institutional social workers have an obligation to assist foreigners in immigration procedures. Besides, city councils are vital institutions in managing family reunification procedures and issuing reports to demonstrate social roots, which are also useful when applying for residence permits. Immigration policies have involved the consolidation of a number of agencies and administrative routines at local level, too. These measures include the following three: 
1) forums for participation, so that integration measures have greater legitimacy; 2) the approval of integration plans as technical planning tools; and 3) the consolidation of a support network involving the third sector (Fernández-Suárez, 2018). However, municipal old politics have been characterised by routine and pragmatism in the measures implemented aimed at reception (see Zapata-Barrero, 2011).

Furthermore, the influence of the ideology of the ruling parties on integration policies is an open debate and more research is needed at both state and municipal level. The two cases examined here show that the confluence of progressive governments formed by citizen platforms give greater relevance to municipal powers than the previous ones, aiming to improve the rights of immigrants, especially of those under irregular status. Notwithstanding, there are differences in the specific cases of Madrid and Barcelona. Below we examine the context and framework of the political forces that have governed the two cities to locate the new municipalism legislatures on the map.

The city of Madrid was governed by conservative forces from 1991 to 2015, ruling a conservative approach (see Table 1). The great commitment with immigrant integration took place during the legislature of 2003-2007 and it was based on promoting universal care, equal access to public services, participation and interculturality. The Madrid Forum based on principles of dialogue and coexistence was launched with this goal in 2006. However, the model was truncated from 2007 due to a shift towards a liberal model of integration under the approach that immigrants are individually responsible for their destiny and economic integration. The idea of interculturality is discarded then, and it is replaced by the 'integration contract.' This approach makes programs more labour-oriented, reducing intercultural programs to a minimum (Rovetta-Cortés, 2014). The city offered basic care services and assistance offices to help with administrative procedures. However, these services were strongly affected by the social cuts of 2008 , particularly those services aimed at coexistence, such as intercultural mediation and social participation. The Immigration Assistance Offices remained open, although declined in number. Madrid's response to the economic recession shows precisely the volatility of local policies committed to inclusion in the context of austerity (see Ambrosini, 2017).

In Barcelona the situation was different (see Table 2). The city has been governed mainly by progressive forces, in addition to the deep-rooted presence of a strong civil society (Eizaguirre, Pradel-Miquel, \& García, 2017). Local immigration policies have been characterised by innovation. Instruments such as specific care services are similar to other cities, however the degree of institutionalisation, consolidation and implementation stands out here (Fauser, 2008). Since 1985, Barcelona is pioneering in creating specific participation mechanisms such as the Immigrant, Migrant and Refugee Service (see Morén-Alegret, 2001). The city also has a dynamic associative network of immigrants and protects ethnic ties (Mora, 2020). In addition, it places greater emphasis on civic integration through the learning of cultural and linguistic values (Caponio, Baucells, \& Güell, 2016; Gebhardt, 2016a). It can also be explained by the dialectic of the differentiated Catalan minority within the hegemonic culture of Spain (Zapata-Barrero, 2017).

At the state level, the liberal paradigm of 'activation policies' prevailed after the economic recession as

Table 1. Contextualisation of multilevel governance in Madrid (1982-present).

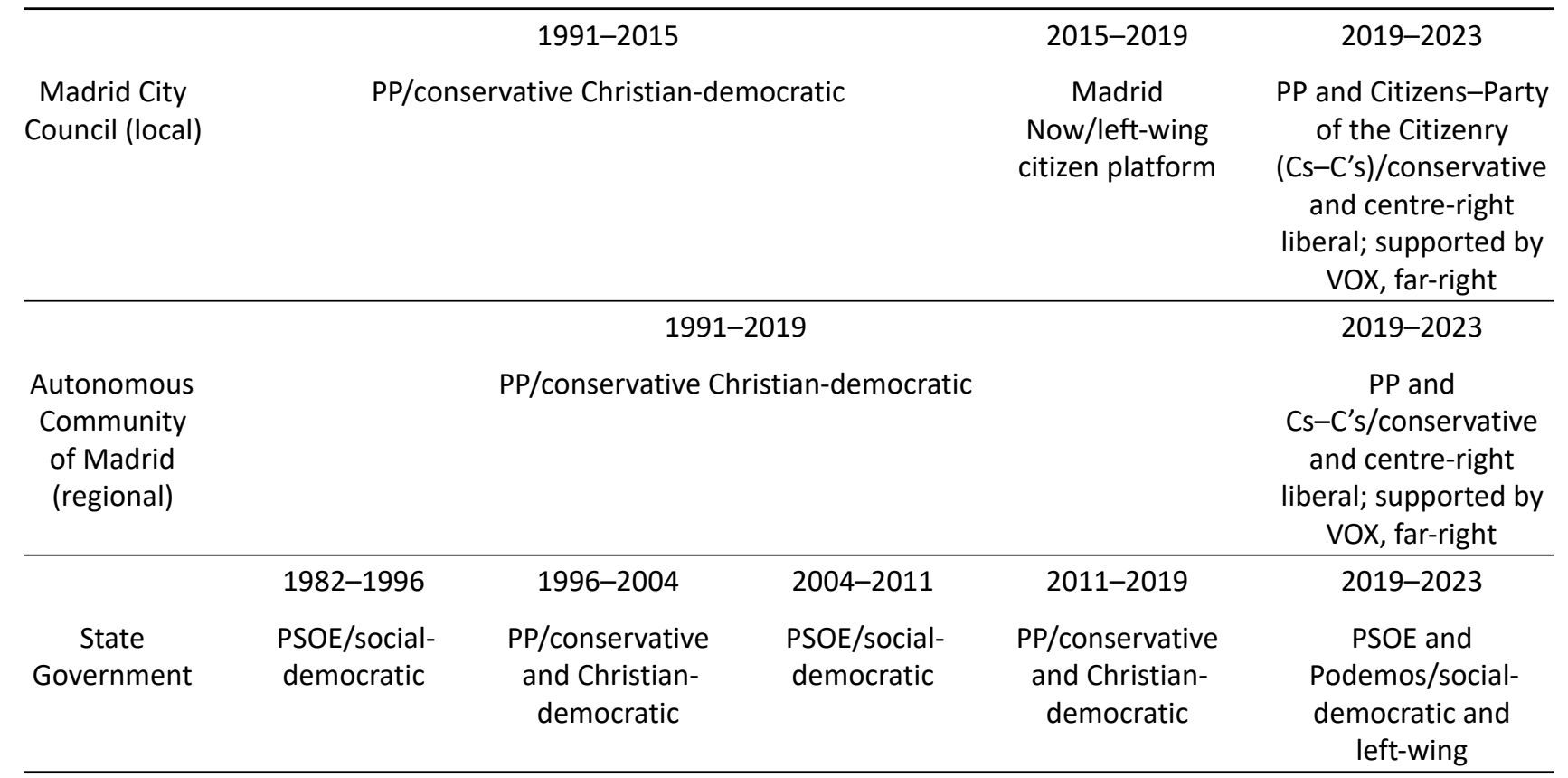

Source: Own elaboration based on electoral results. 
Table 2. Contextualisation of multilevel governance in Barcelona (1982-present).

\begin{tabular}{|c|c|c|c|c|c|}
\hline \multirow[b]{2}{*}{$\begin{array}{l}\text { Barcelona } \\
\text { City Council } \\
\text { (local) }\end{array}$} & 1983-1987 & \multicolumn{2}{|c|}{ 1987-2011 } & 2011-2015 & 2015-2023 \\
\hline & $\begin{array}{l}\text { Socialists' Party of } \\
\text { Catalonia } \\
\text { (PSC-PSOE)/social- } \\
\text { democratic }\end{array}$ & \multicolumn{2}{|c|}{$\begin{array}{l}\text { PSC-PSOE, Initiative for } \\
\text { Catalonia Greens \& Republican } \\
\text { Left of Catalonia (ERC)/ } \\
\text { social-democratic, eco-socialist } \\
\text { and left Catalan nationalism }\end{array}$} & $\begin{array}{l}\text { Convergence and } \\
\text { Union (CiU)/ } \\
\text { Conservative and } \\
\text { Catalan } \\
\text { nationalism; } \\
\text { supported by PP, } \\
\text { conservative }\end{array}$ & $\begin{array}{c}\text { Barcelona in } \\
\text { Common \& PSC- } \\
\text { PSOE/left-wing } \\
\text { citizen platform } \\
\text { and } \\
\text { social-democratic }\end{array}$ \\
\hline & \multicolumn{2}{|c|}{ 1980-2003 } & 2003-2010 & 2010-2015 & $2015-2020$ \\
\hline $\begin{array}{l}\text { Autonomous } \\
\text { Community } \\
\text { of Catalonia } \\
\text { (regional) }\end{array}$ & \multicolumn{2}{|c|}{$\begin{array}{c}\text { CiU/Conservative and Catalan } \\
\text { nationalism }\end{array}$} & $\begin{array}{c}\text { PSC-PSOE, } \\
\text { Initiative for } \\
\text { Catalonia Greens } \\
\text { \& ERC/social- } \\
\text { democratic, } \\
\text { eco-socialist and } \\
\text { left Catalan } \\
\text { nationalism }\end{array}$ & $\begin{array}{c}\text { CiU/Conservative } \\
\text { and Catalan } \\
\text { nationalism }\end{array}$ & $\begin{array}{l}\text { Together for the } \\
\text { Yes \& ERC/Pro- } \\
\text { independence } \\
\text { nationalist } \\
\text { conservative } \\
\text { coalition and left } \\
\text { Catalan } \\
\text { nationalism }\end{array}$ \\
\hline & 1982-1996 & 1996-2004 & 2004-2011 & 2011-2019 & 2019-2023 \\
\hline $\begin{array}{c}\text { State } \\
\text { Government }\end{array}$ & $\begin{array}{l}\text { PSOE/social- } \\
\text { democratic }\end{array}$ & $\begin{array}{l}\text { PP/conservative } \\
\text { and Christian- } \\
\text { democratic }\end{array}$ & $\begin{array}{l}\text { PSOE/social- } \\
\text { democratic }\end{array}$ & $\begin{array}{l}\text { PP/conservative } \\
\text { and Christian- } \\
\text { democratic }\end{array}$ & $\begin{array}{c}\text { PSOE \& } \\
\text { Podemos/social- } \\
\text { democratic and } \\
\text { left-wing }\end{array}$ \\
\hline
\end{tabular}

Source: Own elaboration based on electoral results.

of 2008. These are specific measures that emphasize citizen's individual responsibility to perform economic self-reliance and societal integration. It happened firstly and foremost through gainful employment on the labour market (Gilbert, 2013), but civic integration programs were also established at this time, having a strong assimilationist accent that was specified in the acquisition of linguistic and civic skills (see Caponio et al., 2016; Gebhardt, 2016b).

When the new municipalist fronts came to govern the cities, they had to face state budget cuts that grossly affected social inclusion policies. The response was characterised then by a significant increase in social funds, particularly aimed at improving the life conditions of vulnerable people and strengthening care services thorough municipal assistances offices. Together with these measures aimed at ensuring the continuity of local integration policies, they promoted concrete actions aimed at protecting irregular immigrants, mainly facilitating their access to public services and protection against criminalisation. This is the focus of our analysis in the next section.

\section{The Agenda for Change: New Municipal Policy Alternatives}

The connection between "the transformative politics" of the new municipalism (Russell, 2019) and immigration policy relates to the double dimension of the state's restrictive and punitive turn previously noted. The first has to do with guarantees in the protection of rights and access to social welfare. The second addresses the extension of policing and "crimmigration" control practices based on identification, detention and deportation (Costello \& Mouzourakis, 2016; De Genova, 2016). In this regard, the 2018 data from the Ministry of the Interior show that more than 11,000 people were repatriated at state level, representing an increase of $22 \%$ compared to the previous year. The total number of expulsion and return orders was 58,548 , of which $19 \%$ were executed. And almost 8,000 people were detained at the Foreigners Detention Centres (Defensor del Pueblo, 2019).

The relevant question at this point it is precisely the link between the punitive dimension and the restrictive one in the access to rights and social welfare. Mezzadra and Neilson (2013) note this is produced under a model of citizenship that is based on a "differential inclusion," referred to the nation-state's effort to demarcate non-belonging via law and policy. It denotes that integration is marked by a multiplicity of positions that differentiate and subordinate subjects in society, manifestly restricting access to welfare, wellness and social opportunities (see also Borrelli, 2019; Könönen, 2018).

Analysing the concrete cases of Madrid and Barcelona, we decided to select four political measures aimed at irregular immigrants. This criterion derives from the fact that this group is more exposed to social vulnerability and stigmatisation. Although Spain is characterised by a high acceptance of immigration, the rejection of immigrants is greater when they are in irregular situation 
(OBERAXE, 2017). Moreover, the very intention of adopting measures aimed at incorporating irregular immigrants initially shows a greater degree of commitment, also challenging the restrictive and punitive approach of the state. The measures selected are: 1 ) proactive policies facilitating the registration of irregular immigrants in official censuses, 2) measures to prevent administrative irregularity when already having regular status, 3) measures to ensure access to healthcare, and 4) changes in police protocols to avoid criminalisation and persecution. The implementation of these measures was more intense in Barcelona, as it became the driver for primarily responding to the fragility of immigrants' administrative status.

\subsection{Accessing the Municipal Census}

As we have maintained so far, the municipal census entails the right to access public services and municipal resources regardless of the immigration status. However, we find a high discretion in the requirements that each municipality establishes. Thus, there are cases that deny registration for irregular immigrants, such as the municipality of Vic (Triviño-Salazar, 2020) or the border enclaves of Ceuta and Melilla (Espiñeira, 2020). On the reverse, other municipalities, such as the cases analysed, promote proactive policies for registration. In Barcelona, the City Council modified registering procedures aiming to facilitate registration for those lacking fixed address, that is, people living without lease, in infra-dwellings or in occupied houses (Barcelona City Council, 2018b). By means of inspections carried out by municipal officials, they verify the regular use of the house without the need to have rental lease or the authorisation of the owner. The issuance of these reports facilitated that the number of people under these circumstances registered in the census doubled between 2015 and 2017. In Madrid, the City Council started a pilot project issuing Neighbourhood Cards, first in downtown and then extended to other districts. It established an agreement with social entities so that the headquarters can be used as an address where people can register. City officials from the Department of Social Services we interviewed emphasised the guarantees offered by the Neighbourhood Card as it was a valid document to certify social roots and avoid detentions (I2). Both councils also implemented the issuance of Neighbourhood Reports, as documents to prove social roots, give protection in detentions or avoid expulsion orders (see Fernández-Bessa, 2019).

\subsection{Preventing the Fall in Irregularity}

Barcelona is the most advanced case in developing measures to prevent people do not lose their regular status. The City Council has been innovative seeking labour alternatives such as the extension of the duration of labour contracts aimed at social insertion and public recruit- ment. The rationale was to stabilise the regularisation of people by generating offers from public employment that guarantee the achievement of a work permit. About 100 people were regularised by this measure, but the value of the program is more qualitative than quantitative. Düvell (2011) emphasises the difficulties and scarce mechanisms to obtain residence and work permits as one of the main causes of irregularity in Europe nowadays. He also demonstrates how the process of renewal of those permits is one of the main motives. In this vein, we have found that Barcelona's City Council launched protocols to identify people at risk for non-renewal of work permits and refer them early to municipal employment services.

\subsection{Ensuring Universal Access to Healthcare}

According to the national health survey (National Statistics Institute, 2011, 2017) in Spain, public health coverage for the population aged 0 and over is $99 \%$. This data indicates the quasi-universalization of the public health system, which is an area of competence of the regions. When in 2012 the state approved the modification of the National Health System motivated by efficiency and savings arguments by Law 16/2012 (Spanish Government, 2012b), such reform amended the Aliens Law affecting the right to healthcare. Before that, irregular immigrants had granted equal access under the sole requirement of being registered in the municipal census. This was indicative of the state's initial positioning in favour of the universalisation of healthcare, recognised by the Spanish Constitution (Spanish Government, 1978, art. 43). However, the 2012 amendment limited access to those who fulfil the condition of affiliated to Social Security and, thereby, to those who are 'legal residents.' That meant that the census ceased to be an access title to full health coverage and those under irregular administrative status would only have access in emergencies for serious illness and limited assistance with pregnancy, childbirth and post-partum (Boso \& Vancea, 2016; Peralta-Gallego, Gené-Badia, \& Gallo, 2018). In addition, the contributory logic of the welfare system causes a strong vulnerability among the immigrant population with shorter and more precarious career paths, precisely due to their participation in temporary jobs and the informal economy (Bruquetas-Callejo \& Moreno-Fuentes, 2015). Facing this restrictiveness, the City Council of Madrid launched the campaign: 'Madrid does care: Madrid free of health exclusion.' It consisted of accompaniment and training programs to access public facilities and medical care. The goal was to ensure that all people living in the city have assigned medical professionals. The program incorporated almost 20,000 people into the health system the first year. It offered training for municipal staff, so that they can explain and accompany citizens in the exercise of the right to health. 


\subsection{Changing Protocols for Police Intervention}

The cities of Madrid and Barcelona are paradigmatic cases to understand how policing and crimmigration control operate in Spain (Brandariz-García \& Fernández-Bessa, 2017; Moffette, 2020). State control practices based on selective identifications and collective raids are carried out in urban public spaces aimed at targeting and frightening racialised profiles of immigrants. Identifications take place mainly in downtowns popular neighbourhoods, monitoring the exit of schools, medical centres, markets, call centres and public transport stations. Both city councils adopted measures to counterbalance this punitive functionality of the state. In Madrid, these measures came after the death of the Senegalese street seller Mame Mbaye in March 2018. Immigrant activist organisations, such as the Asociación de Sin Papeles (Association of Undocumented People) and the Sindicato de Manteros y Lateros (Union of Street Sellers), constantly denounced the police harassment suffered by people doing informal street vending. The first measure adopted by the City Council was the modification of the 'Street Sales Instruction.' It incorporated the prohibition of police motorised persecution. It also regulated that police actions should be ordered and planned by a command, avoiding therefore autonomous police interventions. Interventions must be also accompanied by an assessment report ensuring responsibility. In addition, it was launched a pilot project to avoid identifications by ethnic/racial profile that consisted of a good practices protocol and the elimination of efficacy indicators meeting numerical objectives in detentions.

\section{Tensions between Political Will and Institutional Constraints}

As we further explore the institutional change initiated by the new municipalism and the limits found in adopting progressive migration policies, we notice elements of tension between the political will that arises from social movements and the immediate reality of management from within the institutions.

The tension between social movements, partymovements and government action has already been studied in the 'cities for change' (see Calvo-Martínez \& De Diego-Baciero, 2019; Monterde, 2019; Subirats, 2016). In Madrid and Barcelona, this tension has been present throughout the entire 2015-2019 legislature. Based on our empirical work, we find hard frictions to solve between the agenda for change and its political implementation. It is described as "a tension between the project's essence and driving the institution" (in the words of a political advisor from Madrid Now; 11). Activists describe the institution as a complex machinery with established political-administrative inertias, with little capacity for innovation, and established power around the hierarchy of the structure, hindering therefore the implementation of the political agenda.
The demand for the closure of immigration detention centres, which has been central to migrant struggles, illustrates well this friction given the impossibility of materialising the action. The measure was included in the electoral programs of Barcelona in Common and Madrid Now. The attempt was only undertaken in Barcelona, and the strategy consisted of two actions. First, to avoid detention by issuing neighbourhood documents and changing police intervention protocols (as we saw in Section 4). Secondly, the City Council attempted to withdraw the license to use the facility. This is an act under municipal powers, however the process ended up being prosecuted, with long terms that made impossible for the institution to stop the activity during the mandate.

The arrival of the municipalist fronts as a new political actor with a strong activist component also revealed the tension inside/outside the institution. On the one hand, the burden of government management meant a transfer of people from the movement to the institution and, internally, this process was viewed critically insofar as it subtracted activists and weakened the social movements from which they came, as a political advisor from Barcelona in Common stated (14). On the other hand, it also led to friction when defining and communicating the political agenda and it becomes more difficult to differentiate when the movement speaks from when the institution does, pointed out a City Councillor from Barcelona in Common (16).

The priorities of the movement and those of the government also conflicted on specific issues. An important clash was the one that occurred with the manteros and the use of urban public spaces. They are undocumented immigrants who work in street vending. The name of manteros comes from 'blanket,' person who works with the blanket. A blanket is used to expose the merchandise, that is for sale, and it also allows to be quickly collected by folding it. It is an informal activity that is visible and is persecuted by the police. The conflict began in the summer of 2015 when mainstream media reported a growth in number. It was represented as a public security problem and the government was accused of "permissiveness" ("Ada Colau, a permissive mayor"; Gubern, 2016). This prompted the government 'of the Commons' to enforce a regulation on the use of public space preventing concentrations (Barcelona City Council, 2005), when in its electoral program it had promised the immediate repeal of said regulation. The conflict caused a distancing between the government and the social movements in the city, generating tension in the very bases of the political party.

Now, continuing the analysis of the factors that conditioned the capacity for action, we certainly find that the context of austerity imposed severe limits. The municipalists fronts came to an administration subjected to a new budget stability by Law 2/2012 (Spanish Government, 2012a). This law restricted local autonomy, limited the spends of the councils and established the inability to include new services in municipal budgets. 
A catalogue of "innovative policies inspired by other international cities could not be taken under this framework" (City Councillor from Madrid Now remarked; 13). This is one of the elements that could explain why certain services considered strategic were not implemented. The capacity for innovation was limited since the services to be financed within the municipal budget had to have been developed before in the same administration.

Another relevant element has been the strength of the bureaucratic-administrative structure and its ability to perpetuate, making changes in its own functioning difficult. Street-level bureaucrats' testimonies indicate that the constraints are set by "the structure itself," referring to an administrative system that makes change difficult. They also refer to the slowness of the institutions, "the procedures are long and execution times slow" (12). We can define this as the tension between the political change and the institutional management times. In our interviews we also find that, among the elements indicated to overcome these limitations, there was the need to work on resistance coming from within the institution. Resistance to change was stronger in conservative sections like the Police Department, but also in Social Services (12). For example, in the case of housing inspections and reports made by municipal technicians within the proactive census policy in Barcelona. Some municipal workers made a more conservative reading of the law than the city government, so it was necessary internal pedagogy, sensitivity and even training processes (I5).

Key actors in this process are professionals working in areas of cultural and social diversity to the extent they particularly have a certain discretionary scope to apply these measures or programs (Lipsky, 1980). Among the advantages of this leeway is the ability to adapt to individual situations, and among the possible drawbacks is that they can contribute to legal uncertainty or inequality and can frustrate the compliance with policy objectives (Gidley, Scholten, \& Van Breugel, 2018).

Summarising, the governments of the 'cities for change' managed to innovate and implement policies that improved the lives and expanded the rights of immigrants. It was not a collective general political commitment, but rather measures driven by politicians who were once pro-migrants and non-border activists. Government actions caused division and rupture in migrants' social movements, as the Manteros Union illustrates. It will be valuable to include the views of these critical groups in the analysis. Future lines of research could precisely contrast the vision faced between managers and managed, between politicians and social movements. We observe here a fracture in the mutual trust process that led to the emergence of a movement suspicious again of the institutional sphere.

\section{Conclusions}

In Spain, there has been a restrictive and punitive turn in immigration policy that is directly connected to the economic recession and austerity policies as of 2008 . On the one hand, there are strong economic and social cuts in basic welfare services that had had universal coverage, such as healthcare. On the other hand, control mechanisms in the form of identifications and detentions spread throughout the urban territory. In our analysis we have emphasised the links between both dimensions. The restrictive and punitive turn are both strongly connected to the state's production of irregularity, based precisely on the differentiation of profiles under the regular/irregular division. This is linked to a conception in the governance of migration that is based on a differential inclusion that delimits categories of non-belonging and limits citizenship.

Through the study we have intended to illustrate what are the possibilities and limits of radical municipalism in governing the cracks of the immigration control in Spain. Have pro-migrant policies succeeded in protecting and expanding the rights of irregular migrants? Old politics have addressed reception and integration through pragmatism and thinking almost exclusively of those migrants who are in a regular situation, hence the emphasis on civic integration criteria. It has also been shown that restrictive and punitive approaches lead to increased vulnerability and criminalisation of immigrants. At this point, we have also seen how integration policies are conditioned by the ideology of the ruling party, being this an open debate that deserves more attention.

Examining the cases of Madrid and Barcelona and the new approach to immigration during the municipalist fronts (2015-2019), we noted that, if there is political will, cities and local administrations are able to move forward creative solutions. In the analysis we have observed that, together with measures aimed at providing greater resources to services already functioning, such as the attention offices, new policies have been promoted with the primary goal to protect the rights of irregular immigrants. Intervention areas are from pro-active census policies facilitating access to healthcare and other social services, to changes on municipal regulations to avoid administrative irregularity, criminalisation and persecution. From the perspective of the activists and the policymakers interviewed, these city level responses can help to build more inclusive societies in the long run, so far as can build trust between law enforcement agencies and migrant communities. However, we have also observed how governmental actions can also produce divisions within migrants' social movements, as it happened in the case of the Manteros Union, undermining therefore the mutual trust.

Despite the political will we have also found important institutional constraints that limit the action and powers of municipalities when implementing progressive immigration policies. Municipal workers emphasised resistances coming from within the institution. They also highlighted the little capacity to transform the administrative structure and its inertias, such as 
slowness. Moreover, the austerity measures enforced by the state implied a significant reduction in the autonomy of the municipalities, limiting not only budget but also powers and, therefore, cutting off the possibilities of political transformation. With regard to competencies in immigration matters, cities can extend and equate the rights of irregular immigrants, but always within the current legislative framework of the Aliens Law. The measures examined here managed to curb the impact of the exclusion of basic social services such as health. They also contributed to diminish criminalisation and persecution, however they had limited capacity to subvert the logic that underlies the Aliens Law, that is, to alter the irregularity condition. This causes the change to be more symbolic than transformative in quantitative terms. However, despite these limitations and obstacles, the cases of Barcelona and Madrid illustrate well how cities and local administrations are protagonists in providing radical solutions for protecting undocumented migrants. These cases provide concrete measures that may be suggestive to test in other contexts and societies. They show it is possible to oppose institutional practices and make the right to the city more extensible to immigrant populations.

\section{Acknowledgments}

Belén Fernández-Suárez would like to thank the Faber de Olot Foundation (Girona) for hosting her in the Diversity Policies residence in 2019, giving her the right environment and time for writing part of this article. Keina Espiñeira has carried out this work within the framework of the Juan de la Cierva-Formación Postdoctoral Excellence Contract granted by the Ministry of Science and Innovation of the Government of Spain (FJCl-201629926). The two authors want to thank the organisers and the people involved in the Workshop 'Governing the Poor: Migration and Poverty' celebrated at the University of Neuchâtel (Switzerland) in December 2019, where we discussed initial drafts. We also thank the anonymous reviewers for the helpful comments and suggestions in bringing this article to light. We are also grateful for the financial support of ESOMI through the Aid for the Consolidation and Structuring of Competitive Research Units of the Galician University System (ED431C 2018/25, 2019-2021), funded by the Xunta de Galicia.

\section{Conflict of Interests}

The authors declare no conflict of interests.

\section{References}

Gubern, A. (2016, May 26). Ada Colau, una alcaldesa permisiva [Ada Colau, a permissive mayor]. $A B C$. Retrieved from https://www.abc.es/espana/abcicolau-alcaldesa-permisiva-201605260329_noticia. html

Ambrosini, M. (2017). Superdiverstity, multiculturalism and local policies: A study on European cities. Policy \& Politics, 45(4), 585-603.

Arango, J. (2013). Exceptional in Europe? Spain's Experience with Immigration and Integration. Washington, DC: Migration Policy Institute.

Barcelona City Council. (2005). Ordenanza de medidas para fomentar y garantizar la convivencia ciudadana en el espacio público de Barcelona [Ordinance on measures to promote and guarantee citizen coexistence in the public space of Barcelona]. Barcelona: Barcelona City Council.

Barcelona City Council. (2015). Memoria 2015[Municipal immigration Council's reports 2015]. Barcelona: Barcelona City Council. Retrieved from https:// ajuntament.barcelona.cat/novaciutadania/sites/ default/files/documents/10._saier.memoria.2015_ ca.pdf

Barcelona City Council. (2016). Memoria 2016 [Municipal immigration Council's reports 2016]. Barcelona: Barcelona City Council. Retrieved from https:// ajuntament.barcelona.cat/novaciutadania/sites/ default/files/documents/11._saier.memoria.2016_ ca.pdf

Barcelona City Council. (2017). Memoria 2017 [Municipal immigration Council's reports 2017]. Barcelona: Barcelona City Council. Retrieved from https:// ajuntament.barcelona.cat/novaciutadania/sites/ default/files/documents/memoria_saier_cat.pdf

Barcelona City Council. (2018a). Pla de Ciutadania i Immigració de la ciutat de Barcelona 2018-2021 [Citizenship and immigration plan 2018-2021]. Barcelona: Barcelona City Council. Retrieved from https:// ajuntament.barcelona.cat/novaciutadania/sites/ default/files/documents/1._pla_immigracio_i_ ciutadania.pdf

Barcelona City Council. (2018b). Medidas a favor del acceso a la regularidad y prevención de la irregularidad sobrevenida [Measure to favour access to regularity and prevent sudden irregularity]. Barcelona: Barcelona City Council.

Barcelona City Council. (2019). Documento de vecindad [Neighbourhood document]. Barcelona: Barcelona City Council. Retrieved from https://ajuntament. barcelona.cat/novaciutadania/sites/default/files/ documents/document_veinatge_web_2019.pdf

Bauder, H. (2014). Why we should use the term 'illegalized' refugee or immigrant. International Journal of Refugee Law, 26(3), 327-332.

Bauder, H., \& Gonzalez, D. A. (2018). Municipal responses to 'illegality': Urban sanctuary across national contexts. Social Inclusion, 6(1), 124-134.

Berg, M. L., \& Fiddian-Qasmiyeh, E. (2018). Introduction to the issue: Encountering hospitality and hostility. Migration and Society: Advances in Research, 1(1), 1-6.

Blanco, I., Gomà, R., \& Subirats, J. (2018). El nuevo municipalismo: Derecho a la ciudad y comunes urbanos [The new municipalism: Right to the city and urban 
commons]. Gestión y Análisis de Políticas Públicas, 20, 14-28.

Borrelli, L. M. (2019). The border inside: Organizational socialization of street-level bureaucrats in European migration regime. Journal of Borderlands Studies. https://doi.org/10.1080/08865655.2019.1676815

Boso, À., \& Vancea, M. (2016). Should irregular migrants have the right to healthcare? Lessons learnt from the Spanish case. Critical Social Policy, 36(2), 225-245.

Bosworth, M., Franko, K., \& Pickering, S. (2017). Punishment, globalization and migration control: 'Get them the hell out of here.' Punishment \& Society, 20(1), 34-53.

Brandariz-García, J., \& Fernández-Bessa, C. (2017). The managerial turn: The transformation of Spanish migration control policies since the onset of the economic crisis. The Howard Journal of Crime and Justice, 56(2), 198-219.

Bruquetas-Callejo, M., \& Moreno-Fuentes, F. J. (2015). Precarización y vulnerabilidad de la población inmigrante en la España en crisis: El papel del Estado de bienestar [Precariousness and vulnerability of the immigrant population in Spain in crisis: The role of the welfare state]. Panorama Social, 22, 139-151.

Calvo-Martínez, A., \& De Diego-Baciero, A. (2019). Municipalismo democrático: Las organizaciones municipalistas [Democratic municipalism: Municipal organizations]. In L. Roth, A. Monterde, \& A. Calleja López (Eds.), Ciudades democráticas: La revuelta municipalista en el ciclo post-15M [Democratic cities: The municipal revolt in the post-15M cycle] (pp. 231-256). Barcelona: Icaria.

Caponio, T., Baucells, O. J., \& Güell, B. (2016). Civic integration policies from below: Accounting for processes of convergence and divergence in four European cities. Ethnic and Racial Studies, 39(5), 878-895.

Casas-Cortes, M. (2019). Care-tizenship: Precarity, social movements, and the deleting/re-writing of citizenship. Citizenship Studies, 23(1), 19-42.

Christoph, W., \& Kron, S. (Eds.). (2019). Solidarity cities in Europe: Charity or pathways to citizenship: $A$ new urban policy approach. Berlin: Rosa-LuxemburgStiftung.

Costello, C., \& Mouzourakis, M. (2016). Detainability EU law and the detainability of asylum-seekers. Refugee Survey Quarterly, 35, 47-73.

De Genova, N. (2016). Detention, deportation, and waiting: Toward a theory of migrant detainability (Working Paper No. 18). Geneva: Global Detention Project.

de Hass, H., Natter, K., \& Vezzoli, S. (2018). Growing restrictiveness or changing selection? The nature and evolution of migration policies. International Migration Review, 52(2), 324-367.

Defensor del Pueblo. (2019). Informe anual 2018: Mecanismo Nacional de Prevención [Annual report 2018: National Prevention Mechanism]. Madrid: Defensor del Pueblo.

Düvell, F. (2011). Paths into irregularity: The legal and political constructions of irregular migration. European Journal of Migration and Law, 13, 275-295.

Eizaguirre, S., Pradel-Miquel, M., \& García, M. (2017). Citizenship practices and democratic governance: 'Barcelona en Comú' as an urban citizenship confluence promoting a renewed policy agenda. Citizenship Studies, 21(4), 425-439.

Espiñeira, K. (2020). El Sistema Europeo Común de Asilo a examen en la frontera terrestre de Ceuta [The Common European Asylum System examined on the land border of Ceuta]. Ceuta: Instituto de Estudio Ceutíes.

Fauser, M. (2008). Autoridades locales e integración política en ciudades de nueva inmigración: Los casos de Madrid y Barcelona [Local authorities and political integration in cities of new immigration: Madrid and Barcelona cases]. In R. Zapata-Barrero \& G. PinyolJiménez (Eds.), Los gestores del proceso de inmigración: Actores y redes de actores en España y Europa [Managers of the immigration process: Actors and networks in Spain and Europe] (pp. 131-148). Barcelona: Fundación CIDOB.

Fernández-Bessa, C. (2019). A theoretical typology of border activism: From the streets to the Council. Theoretical Criminology, 23(2), 156-174.

Fernández-Suárez, B. (2018). La alteridad domesticada: La política de integración de inmigrantes en España: Actores y territorios [Domesticated alterity: The policy of integration of immigrants in Spain: Actors and territories]. Barcelona: Bellaterra.

Garcés-Mascareñas, B., \& Gebhardt, D. (2020). Barcelona: Municipalist policy entrepreneurship in a centralist refugee reception system. Comparative Migration Studies, 8(15). https://doi.org/10.1186/ s40878-020-0173-z

García-Agustín, O., \& Jørgensen, M. B. (2019). Solidarity cities and cosmopolitanism from below: Barcelona as a refugee city. Social Inclusion, 7(2), 198-207.

Gebhardt, D. (2016a). Rethinking urban citizenship for immigrants from a policy perspective: The case of Barcelona. Citizenship Studies, 20(6/7), 846-866.

Gebhardt, D. (2016b). When the state takes over: Civic integration programmes and the role of cities in immigrant integration. Journal of Ethnic and Migration Studies, 42(5), 742-758.

Gidley, B., Scholten, P., \& Van Breugel, I. (2018). Mainstreaming in practice: The efficiencies and deficiencies of mainstreaming for street-level bureaucrats. In P. W. A. Schoten \& I. van Breugel (Eds.), Mainstreaming integration governance: New trends in migrant integration policies in Europe (pp. 153-168). Cham: Palgrave McMillan.

Gilbert, N. (2013). Citizenship in the enabling state: The changing balance of rights and obligations. In A. Evers \& A.M. Guillemard (Eds.), Social policy and citizenship: The changing landscape (pp. 80-96). Oxford: Oxford University Press.

Gonzalez-Enriquez, C. (2009). Spain, the cheap model: Irregularity and regularization as immigration man- 
agement policies. European Journal of Migration and Law, 11(2), 139-158.

Könönen, J. (2018). Differential inclusion of non-citizens in a universalistic welfare state. Citizenship Studies, 22(1), 53-69.

Lipsky, M. (1980). Street level bureaucracy: Dilemmas of the individual in public services. New York, NY: The Russell Sage Foundation.

López-Sala, A. (2013). Managing uncertainty: Immigration policies in Spain during economic recession (2008-2011). Migraciones Internacionales, 7(2), 39-69.

Madrid City Council. (2016). Memoria anual de integración comunitaria 2016 [Socio-community integration annual reports, 2016]. Madrid: Madrid City Council. Retrieved from https://www.madrid.es/ UnidadesDescentralizadas/IntegracionyEmergencia Social/Publicaciones/MEMORIAINTEGRACION 2016.pdf

Madrid City Council. (2017a). Plan estratégico de derechos humanos 2017-2019 [Strategic human rights plan 2017-2019]. Madrid: Madrid City Council. Retrieved from https://www.madrid.es/ UnidadWeb/Contenidos/Descriptivos/ficheros/ PlanDDHH_Madrid.pdf

Madrid City Council. (2017b). Memoria anual de integración comunitaria 2017 [Socio-community integration annual reports, 2017]. Madrid: Madrid City Council. Retrieved from https://www.madrid.es/ UnidadesDescentralizadas/IntegracionyEmergencia Social/Publicaciones/Memoria\%20de\%20 actividades\%202017.pdf

Madrid City Council. (2018). Memoria anual de integración comunitaria 2018 [Socio-community integration annual reports, 2018]. Madrid: Madrid City Council. Retrieved from https://www.madrid.es/ UnidadesDescentralizadas/IntegracionyEmergencia Social/Publicaciones/Memorias/Ficheros/Memoria_ \%20Actividades_\%202018.pdf

Mezzadra, S., \& Neilson, N. (2013). Border as method, or, the multiplication of labor. Durham, NC: Duke University Press.

Moffette, D. (2020). The jurisdictional games of immigration policing: Barcelona's fight against unauthorized street vending. Theoretical Criminology, 24(2), 258-275.

Monterde, A. (2019). De la emergencia municipalista a la ciudad democrática [From the municipal emergency to the democratic city]. In L. Roth, A. Monterde, \& A. Calleja López (Eds.), Ciudades democráticas: La revuelta municipalista en el ciclo post-15M [Democratic cities: The municipal revolt in the post-15M cycle] (pp. 25-53). Barcelona: Icaria.

Mora, C. G. (2020). Local context, networks ties, and organisation autonomy: Latino civic life in Barcelona and Madrid compared. Journal of Ethnic and Migration Studies, 46(19), 4160-4177. https://doi.org/ $10.1080 / 1369183 X .2018 .1500171$
Morales, L., Anduiza, E., Rodríguez, E., \& San Martín, J. (2008). Capital social, pautas identitarias hacia "los otros": La incorporación cívica de la población inmigrante en Barcelona y Madrid [Social capital, identity patterns towards "the others": Civic incorporation of migrants in Barcelona and Madrid]. Panorama Social, 8(2), 119-142.

Morén-Alegret, R. (2001). Tuning the channels: Local government policies and immigrants' participation in Barcelona. In A. Rogers \& J. Tillie (Eds.), Multicultural policies and modes of citizenship in European cities (pp. 61-84). Aldershot: Ashgate Publishing.

National Statistics Institute. (2011). Encuesta nacional de salud, 2011 [National health survey, 2011]. National Statistics Institute. Retrieved from https://www.ine. es/dyngs/INEbase/es/operacion.htm?c=Estadistica $C \& c i d=1254736176783 \&$ menu=resultados\&idp $=$ $1254735573175 \#$ !tabs-1254736194721

National Statistics Institute. (2017). Encuesta nacional de salud, 2017 [National health survey, 2017]. National Statistics Institute. Retrieved from https://www.ine. es/dyngs/INEbase/es/operacion.htm?c=Estadistica_ C\&cid $=1254736176783 \&$ menu $=$ resultados\&idp= $1254735573175 \#$ !tabs-1254736195650

National Statistics Institute. (2018). Datos del padrón municipal, 2018 [Municipal register data, 2018]. National Statistics Institute. Retrieved from https:// www.ine.es/dyngs/INEbase/es/operacion.htm? c=Estadistica_C\&cid=1254736177012\&menu= resultados\&id $=1254734710990$

OBERAXE. (2017). Informe-encuesta evolución del racismo, la xenofobia y otras formas de intolerancia en España [Report-survey on the evolution of racism, xenophobia and other forms of intolerance in Spain]. Madrid: OBERAXE.

Pedreño, A., Moraes, N., \& Gadea, M. E. (2015). Crisis, inmigración y desposesión de los servicios públicos [Crisis, immigration and dispossession of public services]. In F. Torres \& M. E. Gadea. (Eds.), Crisis, inmigración y sociedad [Crisis, immigration and society] (pp. 99-128). Madrid: Talasa.

Peixoto, J., Arango, J., Bonifazi, C., Finotelli, C., Sabino, C., Strozza, S., \& Triandafyllidou, A. (2012). Immigrants, markets and policies in Southern Europe. In M. Okólski (Ed.), Trends, structures and policy implication (pp. 107-147). Amsterdam: Amsterdam University Press.

Peralta-Gallego, L., Gené-Badia, J., \& Gallo, P. (2018). Effects of undocumented immigrants exclusion from health care coverage in Spain. Health Policy, 122(11), 1155-1160.

Rovetta-Cortés, A. I. (2014). Gatos y aliens: Migración familiar y políticas de integración en la Comunidad de Madrid [Cats and aliens: Family migration and integration policies in the Community of Madrid]. Migraciones, 36, 403-432.

Russell, B. (2019). Beyond the local trap: New municipalism and the rise of the fearlesss cities. Antipode: 
A Radical Journal of Geography. https://doi.org/ 10.1111/anti.12520

Spanish Government. (1978). Constitución Española [Spanish Constitution] (BOE, No. 311, 29/12/1978). Madrid: Spanish Government.

Spanish Government. (1985). Ley Orgánica 7/1985, sobre derechos y libertades de los extranjeros en España [Law on the rights and freedoms of foreigners in Spain] (BOE, No. 158, 03/07/1985). Madrid: Spanish Government.

Spanish Government. (2009). Ley Orgánica 2/2009, sobre derechos y libertades de los extranjeros en España y su integración social [Law on the rights and freedoms of foreigners in Spain and their social integration] (BOE, No. 299, 12/12/2009). Madrid: Spanish Government.

Spanish Government. (2012a). Ley Orgánica 2/2012, de estabilidad presupuestaria y sostenibilidad financiera [Budget stability and financial sustainability law] (BOE, núm. 103, 30/04/2012). Madrid: Spanish Government.

Spanish Government. (2012b). Real Decreto-ley 16/2012, medidas urgentes para garantizar la sostenibilidad del Sistema Nacional de Salud y mejorar la calidad y seguridad de sus prestaciones [Urgent measures to guarantee the sustainability of the National Health System and improve the quality and safety of its services] (BOE, No. 98, 24/04/2012). Madrid: Spanish Government.

Subirats, J. (2016). El poder de lo próximo: Las virtudes del municipalismo [The power of proximity: Virtues of municipalism]. Madrid: Catarata.

Subirats, J. (2018). ¿Repartir desde las ciudades? El nue- vo municipalismo como antídoto a la Europa de la 'austerity' de los estados bloqueados [Distribute from the cities? The new municipalism as an antidote to the Europe of 'austerity' of the blockaded states]. In P. Ibarra Güell (Eds.), Nuevos movimientos sociales: De la calle a los ayuntamientos [New social movements: From the street to the city councils] (pp. 77-100). Barcelona: Icaria.

Treviño, R., \& González-Ferrer, A. (2016). Gestión local de la inmigración en los inicios de la crisis económica [Local management of immigration at the beginning of the economic crisis]. In A. Domingo (Ed.), Inmigración y diversidad en España: Crisis económica y gestión municipal [Immigration and diversity in Spain: Economic crisis and municipal management] (pp. 75-98). Barcelona: Icaria.

Triviño-Salazar, J. C. (2020). Who is you ally? Political parties as elite allies of immigrant associations locally. Journal of Ethnic and Migration Studies, 46(19), 3993-4009. https://doi.org/10.1080/ 1369183X.2018.1526060

Zapata-Barrero, R. (2011). Teorizando el enfoque español: Coherencia de políticas públicas, interculturalidad y gobernanza multinivel [Theorizing the Spanish approach: Coherence of public policies, interculturality and multilevel governance]. In Anuario CIDOB de la Inmigración 2010 [CIDOB Immigration Yearbook 2010] (pp. 276-290). Barcelona: Fundación CIDOB.

Zapata-Barrero, R. (2017). Intercultural policy and multilevel governance in Barcelona: Mainstreaming comprehensive approach. International Review of Administrative Sciences, 83(2), 247-266.

\section{About the Authors}

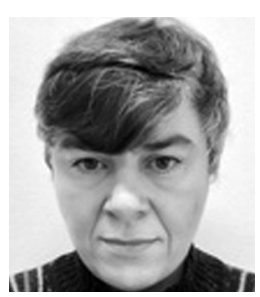

Belén Fernández-Suárez is Senior Lecturer in Sociology at the University of A Coruña. She is Member of the Societies in Motion Research Team (ESOMI). Her main lines of research are migration and local integration policies. At present, she works in the H2020 project “'Welcoming Spaces' in Europe: revitalizing shrinking areas by hosting non-EU migrants" and the R\&D project "Integration and return of the 'new Spanish emigration': A comparative analysis of the Spanish communities in the United Kingdom and France" (EMIGRAREIN).

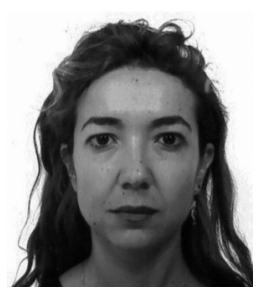

Keina Espiñeira is Postdoctoral Fellow at the Department of Sociology and Visual Communication at the University of A Coruña. Her research focuses on the EU border-migration-asylum policies and technologies. She examines contemporary transformations of borders into processes of socio-spatial ordering. She is also interested in the study of perceptions and representations of borders, mobilities and hybrid identities. Her empirical work is based in the Western Mediterranean, particularly in Morocco and Spain. She is Member of the Societies in Motion Research Team (ESOMI). 